\author{
Diana Dryglas \\ Uniwersytet Jagielloński \\ Krzysztof Wach \\ Uniwersytet Ekonomiczny w Krakowie
}

\title{
Klimat dla rozwoju przedsiębiorczości turystycznej w Małopolsce w świetle badań empirycznych
}

Ostatnie lata to okres wzmożonej aktywności gospodarczej, która owocuje powstawaniem nowych podmiotów gospodarczych, zwłaszcza małych i średnich przedsiębiorstw (MSP). Kierowanie firmą wymaga fachowych umiejętności menedżerskich i gruntownej wiedzy o czynnikach wpływających na funkcjonowanie i rozwój MSP. Na konkurencyjność przedsiębiorstw wpływają zarówno czynniki wewnętrzne, na których opierają się przedsiębiorcy, budując przewagę konkurencyjna, jak i czynniki zewnętrzne, tkwiące w otoczeniu przedsiębiorstwa, które można rozpatrywać w skali makro, mikro oraz mezo, czyli na poziomie regionu. Każda organizacja gospodarcza musi właściwie postrzegać poszczególne elementy swojego otoczenia, aby mogła wśród nich prawidłowo funkcjonować. W praktyce zarządzania ważne jest szczegółowe określenie istotnych dla przedsiębiorstwa czynników i aspektów otoczenia, aby organizacja mogła efektywnie działać. To otoczenie przedsiębiorstwa postrzegane jest subiektywnie przez menedżerów, co wynika głównie ze zróżnicowanych doświadczeń oraz intuicji poszczególnych menedżerów, ich wiedzy oraz kompetencji. Determinuje to zachowania konkurencyjne na rynku, zwłaszcza lokalnym.

Do czynników zewnętrznych wpływających na zachowania konkurencyjne MSP na rynku należy przede wszystkim zaliczyć warunki otoczenia konkurencyjnego i regionalnego. Intensywność zmian mezootoczenia w ostatnich latach wpływa na wzrost znaczenia strategicznego uwarunkowań regionalnego otoczenia biznesu. Każde przedsiębiorstwo dąży do osiagnięcia przewagi konkurencyjnej na rynku lokalnym, krajowym czy wreszcie na międzynarodowym. Realizacja tego celu pociaga za sobą konieczność rozwoju przedsiębiorstwa w wielu płaszczyznach oraz uwzględnianie wielu czynników otoczenia mających wpływ na funkcjonowanie oraz rozwój podmiotu gospodarczego (Wach 2004).

Celem tego artykułu jest ewaluacja regionalnego klimatu dla rozwoju przedsiębiorczości turystycznej w Małopolsce, który z kolei determinuje aktywność gospodarczą tego regionu. Artykuł przedstawia wyniki badań przeprowadzonych w gminach woj. małopolskiego oraz na losowej próbie małych i średnich przedsiębiorstw turystycznych zlokalizowanych w tym województwie ${ }^{1}$.

\section{Założenia metodyczne}

W celu identyfikacji klimatu dla rozwoju przedsiębiorczości turystycznej w woj. małopolskim przeprowadzono dogłębną analizę literatury przedmiotu, w której wiele uwagi poświęcono

\footnotetext{
${ }^{1}$ Artykuł powstał na podstawie badań przeprowadzonych przez autorów tego artykułu w ramach projektu badawczego finansowanego przez Ministerstwo Nauki i Informatyzacji (nr projektu 2 H02D 03325 pt. „Małe i średnie przedsiębiorstwa na polskim rynku turystycznym”, Uniwersytet Jagielloński, Kraków 2004-2006, pod kier. prof. dr hab. Małgorzaty Bednarczyk).
} 
zagadnieniom związanym z otoczeniem przedsiębiorstwa. Na jej podstawie sporządzono wstępną listę uwarunkowań funkcjonowania małych i średnich przedsiębiorstw turystycznych, którą poddano weryfikacji z zastosowaniem metody eksperckiej. Te prace posłużyły do skonstruowania dwóch ankiet skierowanych do:

- małych i średnich przedsiębiorstw turystycznych zlokalizowanych w woj. małopolskim, określonych zgodnie z klasyfikacją PKD,

- gmin woj. małopolskiego.

Ankiety skierowane do przedsiębiorców zostały wysłane do 340 przedsiębiorstw turystycznych, co stanowiło $1 \%$ populacji. Otrzymano 74 kompletne ankiety, co pozwoliło na przeprowadzenie badań na próbie stanowiącej $0,2 \%$ ogółu. Współczynnik zwrotu wyniósł 22\%. Ankietę skierowaną do władz terytorialnych wysłano do wszystkich gmin woj. małopolskiego. Otrzymano 82 kompletnie wypełnione ankiety; wskaźnik zwrotu wyniósł 49,1\%. Badaniami objęto 45\% gmin woj. małopolskiego (82 gminy spośród 182 wszystkich gmin województwa). Gminy miejskie stanowiły $11 \%$, wiejskie $70 \%$, a miejsko-wiejskie $19 \%$ próby badawczej. Ta struktura jest zbliżona do rzeczywistego rozkładu gmin województwa w ujęciu rodzajowym. Łącznie przebadano 60\% wszystkich gmin miejskich, 45\% gmin wiejskich i 40\% gmin miejsko-wiejskich, więc uzyskane wyniki można uznać za reprezentatywne dla całej zbiorowości.

\section{Wyniki badań empirycznych}

Działania poszczególnych gmin woj. małopolskiego na rzecz przedsiębiorstw turystycznych są mało zróżnicowane ze względu na charakter gmin (por. ryc. 1). W celu wskazania różnic w ocenie działań poszczególnych grup gmin w ujęciu rodzajowym, obliczono średnią arytmetyczną ocen. Uśredniona wartość liczbowa mogła przybierać postać ze zbioru liczbowego od 1 do 5 (gdzie 1 -zdecydowanie niekorzystnie, 2 - niekorzystnie, 3 - trudno powiedzieć [przeciętnie], 4 -korzystnie, 5-zdecydowanie korzystnie). Średnia ocena dla gmin miejskich wyniosła 4,0, wiejskich - 4,02, a miejsko-wiejskich - 3,87. Na tej podstawie można wnosić, że najwyższą samoocenę deklarowały gminy wiejskie, przy zastrzeżeniu niewielkich odchyleń (dysproporcji) między średnimi dla badanych grup gmin. Najwyższy odsetek ocen pozytywnych (88,89\% łącznych odpowiedzi ,korzystnie” oraz ,zdecydowanie korzystnie”) odnotowano wśród gmin miejskich oraz gmin wiejskich $(85,96 \%)$, natomiast najmniejszy odsetek odpowiedzi pozytywnych wystapił wśród gmin miejsko-wiejskich $(68,75 \%)$. Gminy miejsko-wiejskie przeważały jednak w ocenach zdecydowanie korzystnych, podczas gdy odsetek tych odpowiedzi dla gmin miejskich był najniższy.

Ocena działań gmin na rzecz przedsiębiorstw turystycznych z uwzględnieniem siedzib oceniających firm jest zróżnicowana (por. ryc. 2). Firmy zlokalizowane w gminie miejskiej Kraków (64,9\% badanej zbiorowości, 48 przedsiębiorstw) nieco częściej oceniały negatywnie działania gminy $(53,33 \%)$ niż przedsiębiorstwa zlokalizowane w pozostałej części województwa (51,72\%). Podobnie oceny pozytywne wystapiły rzadziej w wypadku firm krakowskich $(15,55 \%)$ niż pozostałych (24,14\%). Uśredniona ocena $\mathrm{w}$ przedziale $0-5$ dokonana przez przedsiębiorstwa turystyczne zlokalizowane w gminie Kraków wyniosła 2,4, a uśredniona ocena przedsiębiorstw zlokalizowanych w innych gminach województwa-2,6.

Wskaźnik ogólnej oceny czynników otoczenia regionalnego zbudowano, opierając się na 4 wskaźnikach cząstkowych: wsparciu finansowym w regionie, kadrze pracowniczej w regionie, inicjatywach samorządowych, infrastrukturze regionalnej (por. ryc. 3) ${ }^{2}$. Generalnie rzecz ujmując,

\footnotetext{
${ }^{2}$ Autorzy skupili się na wymienionych 4 kluczowych czynnikach regionalnych z punktu widzenia kierowania i rozwoju przedsiębiorstwa turystycznego.
} 
Ryc. 1. Samoocena działań gmin woj. małopolskiego na rzecz przedsiębiorczości turystycznej

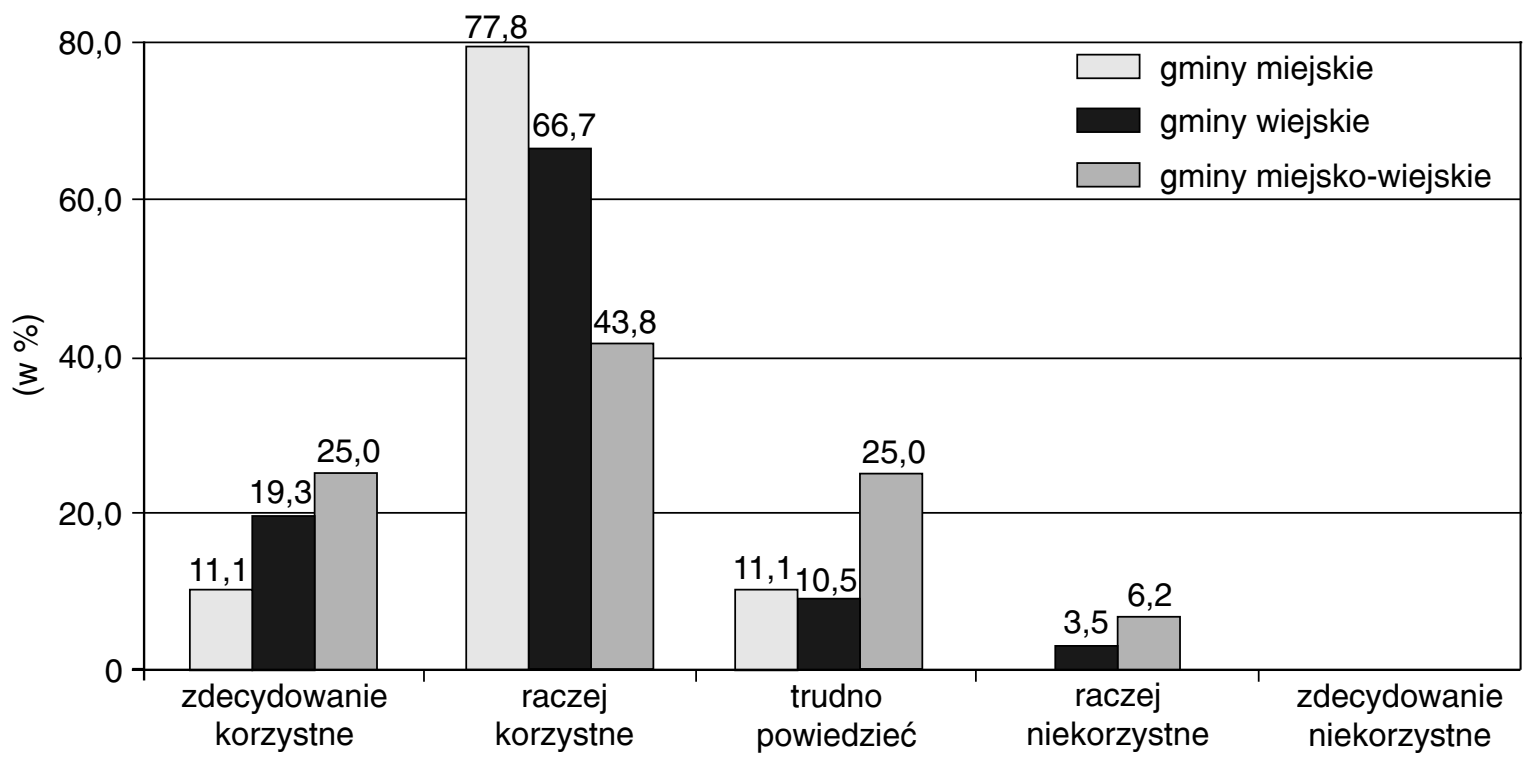

Źródło: opracowanie autorów na podstawie badań empirycznych

Ryc. 2. Klimat dla rozwoju przedsiębiorczości turystycznej w opinii przedsiębiorców z woj. małopolskiego

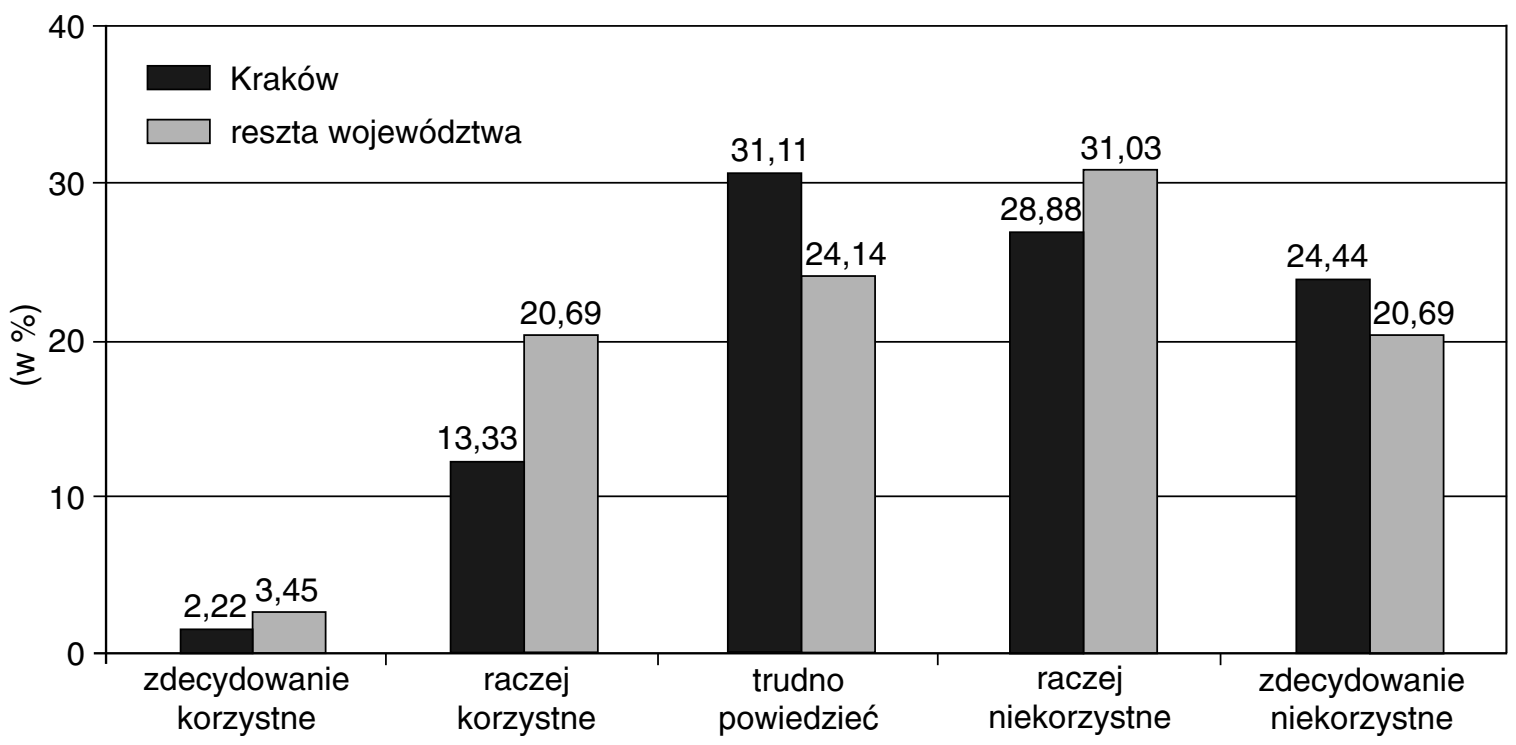

Źródło: opracowanie autorów na podstawie badań empirycznych

zarówno badane przedsiębiorstwa (57,75\%), jak i przedstawiciele władz gminnych (42,39\%) ocenili pozytywnie czynniki otoczenia regionalnego, a wartość wyrażająca ocenę negatywną tego wskaźnika była zdecydowanie wyższa w przypadku przedsiębiorstw $(44,14 \%)$ niż decydentów lokalnych $(23,88 \%)$. Należy podkreślić, że istnieją równomiernie rozkładające się rozbieżności w ocenie przedsiębiorców, podczas gdy ocena dokonana przez władze gminne przyjmuje rozkład normalny. To pozwala wnioskować, że nie ma jednoznacznej opinii wśród przedsiębiorców o wpływie czynników otoczenia regionalnego na rozwój ich przedsiębiorstw. Na przykład: czynniki związane z infrastrukturą stanowią zdecydowaną barierę dla przedsiębiorstw transportowych, ale mają niewielki wpływ na rozwój przedsiębiorstw gastronomicznych. Te same czynniki otoczenia regionalnego mogą być w zależności od rodzaju prowadzonej działalności gospodarczej zarówno stymulatorami, jak i barierami rozwoju. 
Przedsiębiorcom zadano również pytanie „Jak oceniają Państwo swoją miejscowość jako miejsce do prowadzenia biznesu?" (por. ryc. 4). Przedsiębiorcy w znaczącej większości (74,36\%) pozytywnie ocenili swoją miejscowość jako miejsce prowadzenia działalności gospodarczej. Ta wartość jest zdecydowanie wyższa niż wynik ogólnej oceny czynników otoczenia regionalnego (57,75\%) czy poszczególnych wskaźników cząstkowych.

Można zatem sądzić, że przedsiębiorcy - pomimo świadomości występowania barier w rozwoju przedsiębiorstw turystycznych - nauczyli się koegzystencji z otoczeniem oraz wykorzystywania stymulatorów tkwiących w otoczeniu regionalnym.

Ryc. 3. Wskaźnik ogólnej oceny czynników otoczenia regionalnego w Małopolsce

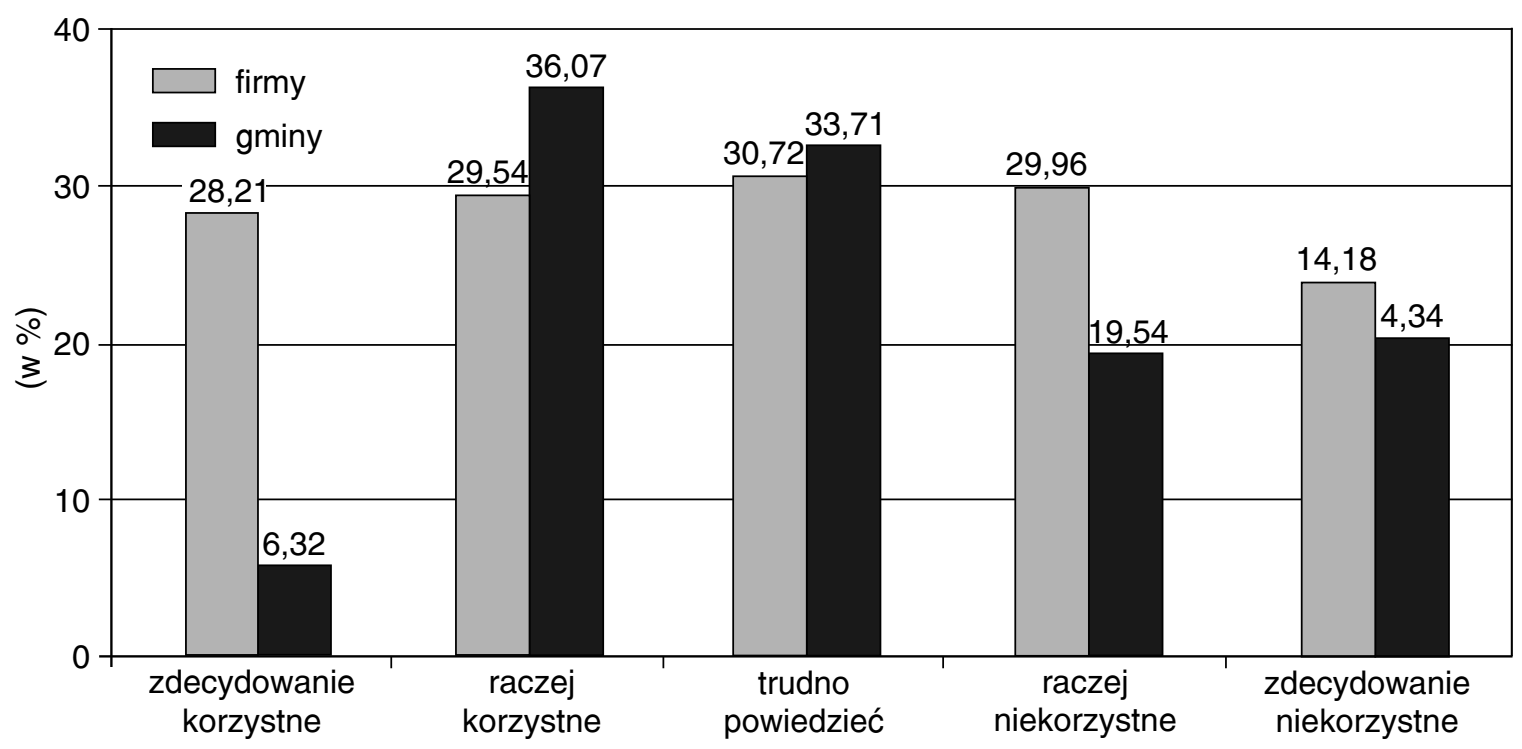

Źródło: opracowanie autorów na podstawie badań empirycznych

\section{Konkluzje}

Woj. małopolskie jest jednym z najbardziej atrakcyjnych przyrodniczo rejonów Polski. Przyczyniło się to do rozwoju turystyki w tym rejonie. Walory turystyczne kwalifikują Małopolskę jako całoroczny region turystyczny. W $2004 \mathrm{r}$. do Małopolski przyjechało ponad 9 mln turystów, a wpływy z ich obsługi wyniosły szacunkowo około 3,3 mld zł. Region przoduje w wielu wskaźnikach charakteryzujących gospodarkę turystyczną. Pod względem wskaźnika korzystania z noclegów przez turystów zagranicznych region zajmuje jedno z pierwszych miejsc w kraju.

Dynamiczny rozwój przedsiębiorczości w turystyce w Małopolsce następuje dzięki m.in. walorom kulturalnym, przyrodniczym i historycznym głównie Krakowa, Zakopanego, Oświęcimia, Wieliczki, Wadowic, ale także setek innych miejscowości. Liczba turystów odwiedzających Kraków liczona jest w milionach i szybko rośnie od czasu wstapienia Polski do Unii Europejskiej. Władze regionalne prowadzą intensywną kampanię reklamującą walory turystyczne i liczą na dalszy napływ turystów.

Dobre warunki rozwoju przedsiębiorczości turystycznej występują w regionie tatrzańskim, głównie ze względu na jego specjalizację turystyczną. W badaniach przeprowadzonych przez M. Bednarczyk i zespół w latach 2003 i 2004 zwrócono uwagę na istotne różnice między wskaźnikiem przedsiębiorczości dla poszczególnych powiatów woj. małopolskiego w ramach danej sekcji PKD: „Dominacja hotelarstwa i transportu w powiecie tatrzańskim wynika z roli, jaką on pełni na turystycznej mapie Polski” (Bednarczyk i in. 2004).Wskaźnik drobnej przedsiębiorczości w regionie tatrzańskim jest od kilku lat jednym z najwyższych w województwie. Podobne wnioski zostały potwierdzone przez M. Bednarczyk i zespół w 2002 r. w badaniach nad produktami turystycznymi Piwnicznej i Szczawnicy oraz rozwojem przedsiębiorczości prywatnej (Bednarczyk 
Ryc. 4. Miejscowość zamieszkania przedsiębiorcy jako miejsce prowadzenia biznesu w woj. małopolskim

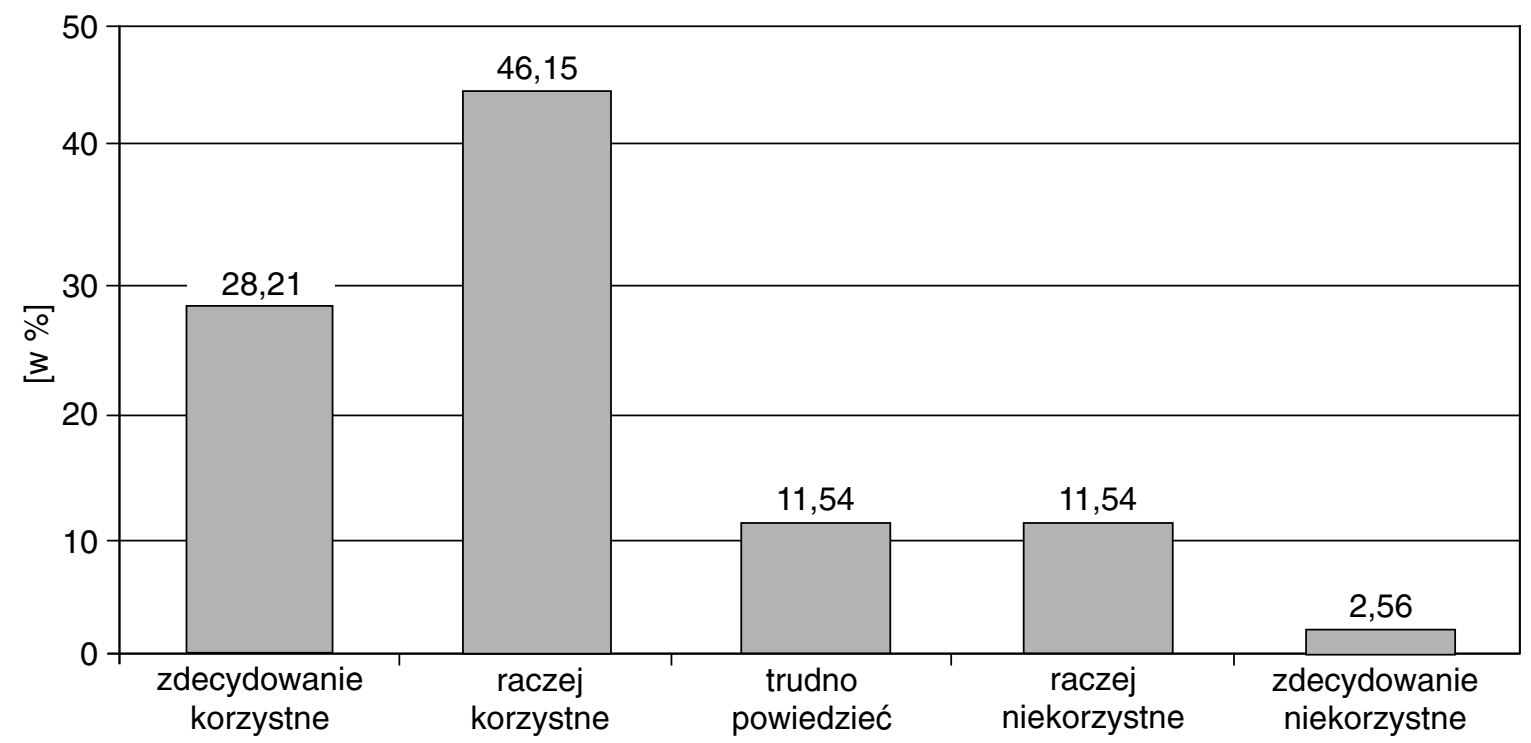

Źródło: opracowanie autorów na podstawie badań empirycznych

i in. 2002). Można wnioskować, że władze lokalne nie zaspokajają potrzeb przedsiębiorców i realizują opracowaną przez siebie strategię rozwoju przedsiębiorczości turystycznej bez uprzedniej analizy potrzeb MSP. Wyniki badań potwierdzają występowanie tzw. luki niedopasowania, czyli niedopasowanie między potrzebami małych i średnich przedsiębiorstw a polityką władz lokalnych wspierającą przedsiębiorczość turystyczną na poziomie regionalnym. „Przed obszarami górskich powiatów nowosądeckiego, nowotarskiego i tatrzańskiego - jako części województwa małopolskiego - stają nowe wyzwania wynikające z potrzeby dostosowania się do współczesnych trendów światowej gospodarki, uwzględnienia w procesach transformacji postulatów Unii Europejskiej i sprostania konkurencji na rynkach” (Bednarczyk i in. 2002).

Badania zmierzające do wyjaśnienia wpływu czynników otoczenia regionalnego na rozwój przedsiębiorstw turystycznych są pionierskie zarówno w krajowej, jak i międzynarodowej literaturze przedmiotu. Na podstawie ich wyników można stwierdzić, że te czynniki odgrywają kluczową rolę w rozwoju regionalnej przedsiębiorczości turystycznej. Przedstawione wyniki wyznaczaja kierunki dalszych badań, w szczególności w zakresie regionalnych determinant rozwoju przedsiębiorstw turystycznych oraz obszarów budowy ich przewagi konkurencyjnej. Jest bowiem potrzeba skonstruowania modelu thumaczącego wzrost przedsiębiorczości turystycznej, który - oprócz czynników związanych z osobą założyciela oraz specyfiką firmy turystycznej - uwzględniłby również czynniki związane z otoczeniem regionalnym jako determinanty przeżycia i sukcesu nowych firm. W wyniku analizy zebranych materiałów sformułowano następujące wnioski:

- wśród badanych przedsiębiorców zaobserwowano wysoką inercję, która przejawia się niską interakcją przedsiębiorstw turystycznych z pozostałymi podmiotami otoczenia regionalnego. Niespełna $20 \%$ badanych przedsiębiorców korzysta z ośrodków wsparcia małych i średnich przedsiębiorstw turystycznych;

- zastanawia niski poziom wiedzy przedsiębiorców o otoczeniu biznesu, zarówno w aspekcie przedmiotowym, jak i podmiotowym. Był to jeden z głównych powodów nieskorzystania z pomocy ośrodków wsparcia małych i średnich przedsiębiorstw turystycznych $(50,34 \%)$ i niezrzeszania się w ramach samorządu gospodarczego $(24,77 \%)$;

- zaobserwowano wyraźne niedopasowanie inicjatyw samorządowych do potrzeb przedsiębiorstw turystycznych, potwierdzone opiniami o polityce gminy wśród przedsiębiorców z jednej strony i samooceną działań gmin - z drugiej. Decydenci lokalni byli bardziej skłonni do 
pozytywnej samooceny, jednak weryfikacja ich działań dokonana przez przedsiębiorców nie była już taka przychylna;

- wobec dynamiki zmian w otoczeniu (również regionalnym) oraz aktualnych potrzeb przedsiębiorców lokalni decydenci będą zmuszeni do stałego monitoringu oraz aktualizacji swoich działań na rzecz wspierania przedsiębiorstw turystycznych.

\section{Literatura}

1. Badania ruchu turystycznego w Małopolsce, 2004, Małopolska Organizacja Turystyczna, Kraków

2. Bednarczyk M. i in., 2002, Ekologiczna kolejka górska elementem zrównoważonego rozwoju regionu turystycznego w Polsce, w ramach projektu „Europejska Inicjatywa EUREKA E! RAIL MOUNT”, Uniwersytet Jagielloński, Kraków (maszynopis powielony)

3. Bednarczyk M. i in., 2004, Małe i średnie przedsiębiorstwa w Polsce a integracja europejska, Wydawnictwo Akademii Ekonomicznej w Krakowie, Kraków

4. Diagnoza, analiza i ocena kondycji sektora MŚP w Krakowie na podstawie badań ankietowych, 2004, Urząd Miasta Krakowa, Kraków (maszynopis powielony)

5. Małopolska w liczbach, 2004, Urząd Marszałkowski Województwa Małopolskiego, Kraków

6. Rapacz A. i in., 2001, Przedsiębiorstwo turystyczne w gospodarce rynkowej, Wydawnictwo Akademii Ekonomicznej we Wrocławiu, Wrocław

7. Wach K., Istota otoczenia regionalnego $w$ funkcjonowaniu matych $i$ średnich przedsiębiorstw [w:] „Prace Naukowe Akademii Ekonomicznej im. O. Langego we Wrocławiu”1023/2004 pt. Gospodarka lokalna i regionalna w teorii i praktyce, R. Brol (red.), Wydawnictwo Akademii Ekonomicznej we Wrocławiu, Wrocław

8. Wach K., 2005, Model badania wptywu otoczenia regionalnego na rozwój małych i średnich przedsiębiorstw [w:] Uwarunkowania rozwoju i konkurencyjności regionów, Z. Zioło (red.), Wyższa Szkoła Informatyki i Zarządzania w Rzeszowie, Kraków-Rzeszów

9. Wach K., Rola państwa i samorzqdu terytorialnego w rozwoju małych i średnich przedsiębiorstw [w:] „Zeszyty Naukowe Uniwersytetu Gdańskiego, Prace i Materiały Wydziału Zarządzania”, 2/2004, Uniwersytet Gdański, Sopot

\section{Climate for Tourist Entrepreneurship in Małopolska on the Basis of Empirical Research}

The paper elaborates on the influence of regional factors (mezoenvironment) on tourist enterprises' development in the region. These factors create so called favorable regional climate for tourist entrepreneurship development. Analyzing impact of mezzoenvironment factors on tourist enterprises development, the authors limit themselves only to small and medium-sized tourist enterprises considering their dominant character in tourist sector, as well as the key significance for development of entrepreneurship and region or country competitiveness. The article presents results of empirical research conducted on a random sample of small and medium-sized tourist enterprises in Małopolska Province. 